\title{
T.T. Cloete: prospekteerder van die albasterblou waterplaneet - 'n inleiding
}

Heilna du Plooy

Departement Afrikaans en Nederlands

Potchefstroomse Universiteit vir $\mathrm{CHO}$

POTCHEFSTROOM

\begin{abstract}
T.T. Cloete: prospector of the planet earth

In this article the publication of this special issue of Literator is motivated by giving an introduction to the work of T.T. Cloete as teacher of literature, as critic and as poet. The contributions in the journal are then discussed and similarities and differences in the articles are indicated. The idea is put forward that an intertextual web, echoing the intertextual relations in the poetry and prose, is formed by the various views in the articles. The article concludes with an extended bibliography of studies on the work of T.T. Cloete.
\end{abstract}

\section{Opdrag}

Hierdie nommer van Literator word opgedra aan prof. T.T. Cloete. Hy het op 31 Mei 1994 sewentig geword en dit is met dié mylpaal in gedagte dat die redaksie van Literator besluit het om 'n spesiale nommer van die tydskrif te laat verskyn. Met die spesiale nommer wil die redaksie aan prof. Cloete waardering betuig, nie net vir sy werk as kreatiewe skrywer nie, maar ook aan hom as persoon. Literator word in Potchefstroom bestuur en gepubliseer en omdat prof. Cloete so lank aan die PU vir $\mathrm{CHO}$ verbonde was en steeds in Potchefstroom woon, is dit vir die redaksie 'n voorreg om op hierdie wyse aan hom erkenning te gee.

\section{Cloete as gewaardeerde en merkwaardige figuur}

Elke literatuur het sy merkwaardige figure. En literêre figure verkry hierdie etiket om ' $n$ verskeidenheid van redes. T.T. Cloete is onteenseglik een van die merkwaardige figure op die Afrikaanse literêre toneel. As literator, kritikus, digter, dramaturg, prosaskrywer en psalmverwerker (min of meer in chronologiese volgorde) het hy oor jare 'n reputasie opgebou en hierdie reputasie groei steeds. As 'n mens soveel hoede gedra het in jou lewe en steeds Literator 16(3) Nov. 1995:1-16

ISSN 0258-2279

1


aktief is in hierdie rolle, is dit seker nie moeilik om te begryp waarom so 'n persoon as merkwaardig beskryf word nie.

Tog gaan dit nie net om wat 'n mens doen nie, maar juis en veral oor hoe jy dit doen. Cloete het baie dinge gedoen: klasgegee, navorsing gedoen, kritiek beoefen en hy doen nog steeds baie dinge: skryf, beoordeel manuskripte, verwerk en dig psalms om, maar dit is vir die kwaliteit, die styl en die aard van wat hy doen dat hy gerespekteer word meer as vir die omvang of verskeidenheid daarvan.

As ' $n$ mens bestek wil neem van die werksaamhede van ' $n$ lewe, het jy daarvoor ' $n$ hele boek op sigself nodig en hierdie inleiding wil geen omvattende verslag van Cloete se lewe en werk gee nie. Ter wille van die motivering en waardering waaruit die gedagte van die spesiale nommer van Literator gegroei het, is dit egter tog nodig om aan te dui waarop sy reputasie gegrond is.

Nadat hy sy akademiese opleiding aan die PU vir CHO met verskeie onderskeidings voltooi en sy doktorale studie in Amsterdam afgehandel het, gee T.T. Cloete vir bykans dertig jaar lank klas aan die PU vir CHO. In hierdie tydperk het hy by honderde studente 'n liefde vir die letterkunde en veral die Afrikaanse letterkunde geïnspireer. Vir hierdie entoesiastiese en toegewyde dosent met sy gemaklike en charismatiese styl van klasgee en warm persoonlike kontak met studente het daar oor jare byna 'n soort nie-amptelike bewonderaarsklub onder oudstudente ontstaan, mense wat nou sy kreatiewe werk met toegeneentheid lees en wie se waardering vir hom ook groot waarde het.

Cloete was tydens sy akademiese loopbaan ook kritikus en selfs polemikus, aangesien sy wakker en maklik gestimuleerde intellek noodwendig tot hierdie soort aktiwiteit en reaksie gelei het. Natuurlik is alle kritiese uitsprake nie altyd 'korrek' nie en vanselfsprekend dateer uitsprake ook, maar die feit bly staan dat Cloete oor baie jare uitvoerig oor die Afrikaanse literatuur geskryf het en so baie bygedra het tot die korpus vakliteratuur waaroor daar vandag beskik word. In sy veelvuldige geskrifte word nie net oor die literatuur as sodanig geskryf nie, maar Cloete se eie poëtika kan ook daaruit afgelei word, sodat hy saam met Van Wyk Louw en Opperman genoem kan word as skrywers wat meewerk tot die totstandkoming van 'n eie Afrikaanse literêr-teoretiese en poëtikale tradisie.

Vir T.T. Cloete het die literatuurstudie egter nie by lesings vir studente en literêre kritiek opgehou nie. As literatuurwetenskaplike het hy die eerste departemente vir Algemene Taal- en Literaturwetenskap (eers aan die Universiteit van Port Elizabeth en daarna aan die PU vir $\mathrm{CHO}$ ) tot stand 
gebring en veel gedoen om die wetenskaplike bestudering van taal en literatuur in Suid-Afrika te bevorder en te ontwikkel. Hy het altyd 'n hoë premie geplaas op navorsing en het nie net self voortdurend bly navorsing doen nie, maar het ook kollegas en studente aangemoedig en gehelp. Een van die groot navorsingsprojekte onder sy leiding wat 'n substansiële bydra tot die vakgebied in die breë gemaak het, is die projek wat uitgeloop het op die omvangryke Literêre terme en teorieë wat in 1992 verskyn het.

In 1980 debuteer Cloete op 56-jarige ouderdom met die digbundel Angelliera en voeg hiermee ' $n$ hele nuwe dimensie aan sy beeld in die literêre wêreld toe, 'n dimensie wat algaande prominenter word. Tans is hy inderdaad primêr as digter bekend. Waar hy as akademikus reeds verskeie toekennings ontvang het (vir 'n volledige lys van toekennings, vgl. Bylaag 1), ontvang hy byna al die literêre pryse in Suid-Afrika vir sy kreatiewe werk. Hy het die belangrikste prys vir die Afrikaanse literatuur, die Hertzog-prys, reeds twee keer ontvang, en wel vir Allotroop en Idiolek in 1987 en vir Met die aarde praat in 1993.

Cloete se poësie staan uit hoofsaaklik vanweë die tegniese voortreflikheid daarvan, die skopus van onderwerpe en temas wat hy betrek en die wye register van ervaring en emosie wat in die poësie tot lewe kom. Hy het egter ook reeds 'n bundel kortverhale en 'n drama gepubliseer. In die kreatiewe werk speel sy wye literêre verwysingsveld 'n groot rol asook sy wye belesenheid in die filosofie en 'n wye kennis van verskillende kunsvorme en natuurwetenskaplike navorsing. Dit maak Cloete se werk 'n uiters vrugbare en gewilde objek van literêre en literatuurwetenskaplike studie en navorsing.

Tans wy hy 'n groot deel van sy kreatiewe energie aan die omdigting van die Psalms en werk hy aktief mee aan die projek van die Nederduits Gereformeerde, Nederduitsch Hervormde en Gereformeerde Kerke om 'n nuwe Psalmberyming daar te stel.

\section{Die artikels in hierdie nommer van Literator}

In hierdie nommer van Literator word daar geen omvattende beeld van Cloete se kreatiewe en akademiese werk gegee nie - dit sou trouens nie moonthk wees binne die bestek van so 'n tydskrifnommer nie. Daar is egter gepoog om artikels van gehalte te versamel oor verskeie aspekte van sy werk. Die Literarubriek is ook aangepas by die tema van die nommer en daarin verskyn werk van Cloete self maar ook werk oor hom.

Die eerste twee artikels handel oor Cloete se prosa, oor die verhale in Die waarheid gelieg. Hierdie bundel kortverhale het in 1984 verskyn het en is die enigste kreatiewe prosawerk wat Cloete tot nou toe gepubliseer het. In hierdie 
nommer van Literator verskyn daar egter weer twee verhale waarmee hy die stilte in sy prosawerk verbreek.

Elize Botha ondersoek in die artikel "Die boek Job as bron van intertekste vir 'Wie weet?" die verband tussen die boek Job in dic Bybul un die verhaal "Wie weet?". In die artikel toon sy aan hoedat die intertekstuele saamlees van die twee tekste die leser in staat stel om die verhaal "Wie weet?" op 'n bepaalde manier te voltooi, hoe 'n bepaalde 'betekenis' en sin deur die intertekstuele verband in die teks van die verhaal ingedra word. Op dié manier word die verhaal ' $n$ ondersoek van lyding en sluit dit aan by hierdie deurlopende tema in Cloete se hele oeuvre.

Deur te soek na 'n moontlike antwoord op die vraag "Op welke wyse word die waarheid gelieg?" wend Heilna du Plooy 'n poging aan om die aard van Cloete se verhale te omskryf. Die verhale word op grond van die bepaalde wyse van fokalisasie - spesifiek die afstandelikheid van die fokalisator - vergelyk met die verhaalkuns van Franz Kafka en Jorge Luis Borges. Die stelling word gemaak dat die fokalisasie in ' $n$ verhaal verband hou met die epistemiese posisie en visie van die abstrakte outeur en dat die talige aard van die verhaal, dit wil sê die proposisies wat in die verhaal gebruik word, die epistemologiese implikasies van die fokalisasie kan oordra. Die verhale word beskryf as verhale van verwondering en vraagstelling, waar volgehoue vraagstelling gesien kan word as ' $n$ besondere soort geloofsbelydenis. Deur die verhale saam te lees met bepaalde verbandhoudende gedigte word enkele slotopmerkings gemaak oor die tekste ten opsigte van lewensbeskoulike en poëtikale aspekte.

Hein Viljoen skryf oor "Die fenomenologie van T.T. Cloete" en onderskei en analiseer vier fasette van die digterlike kyk in die poësie van T.T. Cloete, naamlik die versamelsien, die sien van korrespondensies, die deologiese oog en die fenomenologie van refleksie. Deur te verwys na 'n groot aantal gedigte lê hy onder meer verbande tussen die filosofie van Descartes en Husserl en die poësie van Cloete. Die manier van kyk, die visie, die hele kwessie van fokalisasie speel dus ook in hierdie artikel oor die poēsie 'n belangrike rol. Viljoen tipeer die versamelsien as 'n "geleerde, universele soort sien" wat eksplisiet talig realiseer en kommunikeer, terwyl die raaksien van korrespondensies volgens hom afhanklik is van 'n bepaalde fenonenologiese dimensie, ' $n$ "universeel, vaste en betroubaar kenbare dimensie" waarin hy dan 'n bepaalde armoede vind wat in ander nie-korresponderende gedigte getransendeer word. Die deologiese oog, dit wil sê die kyk van die deoloog, die student van Deus, soek voortdurend na tekens, na spore, na "insinjes" van God en volgens Viljoen is dit veral in later bundels duidelik dat God Homself vir die digter verberg. In 'n gedig soos "Blydskap" gaan dit eksplisiet oor die manier 
waarop die waarnemer (die digter) 'n toneel begryp en dan sien dat uiteenlopende dinge mekaar bewus en wedersyds kan ken, sodat daar gepraat word van 'n fenomenologie van refleksie. Ten slotte word gestel dat Cloete se manier van kyk 'n transendentale kyk is; vir die digter kry verskynsels hulle betekenis en plek binne God se orde, maar soos gesien deur die digter. Dit vorm vir Viljoen 'n egologiese stelsel waarvan die implikasies kortliks in die artikel aangetoon word.

Die dinamiese interaksie tussen 'n bronteks en die resepterende teks word deur Rensia Robinson as vertrekpunt geneem vir haar lesing van die gedig "Van Hom en my" in die artikel "Jukstaposisie van Hom en $m y$ - die digter as hermeneut". Omdat die bronteks die Bybel is, is die intertekstuele lees veel komiplekser. Die rede hiervoor is die lang tradisie van die Christelike godsdiens en teologie waarin die Bybel volgens ' $n$ verskeidenheid van hermeneutiese style gelees is. Sy wys op die verband tussen die struktuur van jukstaponering in die Hebreeuse poësie en dieselfde ordeningsbeginsel in Cloete se werk en ook op die verskillende ander intertekstuele verbande in die gedig (Martin Buber, William Blake, Dante). Die hooffokus van die artikel val op die geordende en ordenende struktuur en werking van die gedig wat dan ook met grafiese voorstellings toegelig word, met die suggestie dat die maksimale interaksie van poëtikale middele en verhoudinge meerdimensionele betekenisgenerering moontlik maak. Die artikel sluit af met die konklusie dat die digter in hierdie gedig as hermeneut werk, as boodskapper teen eie beperkinge in God probeer sien en dié sien verwoord. So word die gedig 'n doksologie in aansluiting by die doksologie in Job 9 .

Ena Jooste maak ' $n$ indringende ontleding van die "Idiolek van T.T. Cloete" toegespits op die bundel Idiolek. Die skryfster gee aandag aan 'n verskeidenheid aspekte van Cloete se werk deur die eiesoortige hantering van poëties-tegniese aspekte (die tematiese, leksikaal-semantiese en morfologiese, fonies-ritmiese, sintaktiese en tipografiese aspekte) aan te toon. Sy gee verder aandag aan die religieuse dimensie in die bundel en bespreek die intertekstuele inslag van die poëtiese transkripsies binne hierdie raamwerk. Die bundel Idiolek word verder binne die Cloete-oeuvre geplaas deur te wys op deurlopende temas en tegnieke sodat 'n groot hoeveelheid inligting aangaande Cloete se tematiese en poëtiese werkwyse hier aan die orde kom.

Fanie Olivier belig die ekologiese implikasies van Cloete se verse oor die natuur en sluit so aan by die kontemporêre gesprek oor ekologiese en bewaringkwessies, dit wil sê die 'groen' gesprek. Sy artikel met die titel "hy maak die kafhok groen - aantekeninge by T.T. Cloete as ekoloog op rym" toon aan hoe Cloete nie net die natuur 'verken' nie, maar die bevindinge en sieninge ook 
poëties 'verwoord'. Olivier plaas hierdie benadering van die natuur teen die agtergrond van Cloete se teologiese verankering: in die poësie word die samehang van natuurdinge belig en die orde van die natuur word in die poësie geëggo. Ten slotte word die verantwoordelikheid van die mens teenoor en as deel van die ekosisteem en die kosbaarheid van ons planeet uitgelig as ekologies-bewuste temas in Cloete se werk.

Die intertekstuele lading in Cloete se poësie kom in byna al die artikels ter sprake, maar Leona Venter bespreek die rol van die intertekstuele verbande veral vanuit die oogpunt van die letterkundedosent met haar bydrae "Fragmente sloer in ons ore - die reaktivering van ouer tekste in die oeuvre van T.T. Cloete". Sy neem die standpunt in dat Cloete se oeuvre 'n ideale voorbeeld is om die verweefdheid van die literatuur en die tekstualiteit van die literêre teks aan studente te illustreer. Die aantoon van intertekstuele verbande van poëtikale aard asook die verbande tussen die verse in 'n bepaalde bundel word gevolg deur 'n bespreking van die geïmpliseerde "persoonlike kanon van die digter". Cloete se poësie is intertekstueel verbonde aan geskrifte, literêr en filosofies en religieus van aard, in sowel Afrikaans as in verskillende Europese tale, sodat van die leser van hierdie poësie by uitstek 'n bepaalde lesersingesteldheid verwag word, 'n ingesteldheid wat ander tekste, kodes en tekens soek, afdraaipaaie vind en volg.

Die verband tussen die struktuur van die bundel Driepas en 'n Gotiese katedraal, spesifiek die Chartres-katedraal in Frankryk, word in die artikel "Die taal as katedraal: Driepas van T.T. Cloete" deur Anna van Jaarsveld en Tom Gouws aangetoon. Die getalle en patrone in die argitektoniese ontwerp van die katedraal vorm deel van die Middeleeuse signifikasiesisteem en dit word in verband gebring met Cloete se voorliefde vir tektoniek en tektoniese samehang soos blyk uit kritiese en kreatiewe tekste. Meer nog, die merkwaardige strukturele ooreenkomste tussen die bundel as geheel en die katedraal word inderdaad aangetoon, sodat met reg gesê kan word dat in die bundel Cloete 'n katedraal gebou het.

Die intertekstuele verhoudinge tussen die poësie en poëtika van Cloete en die Nederlandse digter Marthinus Nijhoff is die ondersoekterrein in die artikel "Die interfererende kontoere van Nijhoff en Cloete se poëtika" deur Adéle Nel en Tom Gouws. Die versinterne sowel as die verseksterne poëtikale inligting word aangedui en bespreek in ' $n$ gesprek wat wentel om die gedig "loopskrif in 'n vakansiehotel" uit Idiolek en waarin verskillende aspekte van die konsep van die 'raam' kreatief ontgin word. Die konklusie word bereik dat Cloete se werk binne die poëtikale tradisie van 'taaleiesinnigheid' geplaas kan word, maar dat hy 'n eie stempel daarop afdruk en so die Afrikaanse literêre tradisie verruim. 
Die gedig "Kameelperd" word in detail ontleed deur Marthinus Beukes in die artikel "Hibriditeit in 'Kameelperd' Goties geteken". Die ontleding berus op die aanname dat die kohesie tussen tekselemente 'n koherente leeshandeling tot gevolg het. Met verwysing na opvattings uit die linguistiek word die stelling gemaak dat grammatikale bindinge in 'n teks 'n verweefdheid bewerkstellig wat, indien dit in samehang beskou en gelees word, tot 'n koherente interpretasie meewerk.

\section{Ook'n web met baie raakpunte}

Uit die studies blyk dat sekere aspekte van Cloete se werk en sy poëtika herhaaldelik in die fokus van die ondersoeke kom staan, hoewel telkens vanuit ' $n$ ander hoek beskou of met ' $n$ ander klemplasing. Net soos die poësie en prosa van die skrywer, vertoon die artikels in die bundel ook onderliggende bindinge, patrone en samehange.

Die visie van die digter, hetsy as die fokalisasie in die verhale of die verse of die 'siening' van die digter, word in die artikels van Elize Botha, Heilna Du Plooy, Hein Viljoen en Rensia Robinson ondersoek en in verband gebring met epistemologiese en lewensbeskoulike kwessies.

Intertekstualiteit vorm ' $n$ deurlopende draad in al die studies, en filosofiese, literêre of poëtikale intertekstuele verbande tussen Cloete se werk en dié van skrywers in ander tale en kulture word in verskeie artikels aangetoon en ondersoek. Name van filosowe soos Pascal, Husserl en Descartes kom in verskeie artikels voor, soos ook die name van verskeie Nederlandse kunstenaars soos Nijhoff en Revius. Die teks wat die opvallendste figureer is die Bybel van die Christelike geloof en veral die boek Job. Die kompleksiteit van selfs oënskynlik eenvoudige werk bied via intertekstuele lees 'n haas onoorsienbare terrein van ondersoek soos blyk uit al die artikels maar veral dié van Louise Viljoen, Leona Venter, Adéle Nel en Tom Gouws.

Die retoriese voortreflikheid en kompleksiteit van Cloete se werk word voortdurend deel van die gesprek oor sy werk en blyk hier veral uit die bydraes van Ena Jooste, Louise Viljoen en Marthinus Beukes. Byderwetse teoretiese en ideologiese kwessies kom ter sprake waar sowel Hein Viljoen as Fanie Olivier die aandag vestig op die ekologiese implikasies van die poësie, terwyl die verhouding tussen Cloete se werk tot die twintigste-eeuse relativisme ter sprake kom by Heilna du Plooy en Hein Viljoen.

Die meeste artikels het as vertrekpunt en doel die vind, omskryf en verduidelik van sleutels tot die werk van Cloete, hetsy vanuit retoriese of intertekstuele invalshoek. As sodanig word die werk van Cloete beskryf en geïnterpreteer 
vanuit 'n waarderende en instemmende hoek. Hein Viljoen se benadering volgens die kontemporêre literêr-teoretiese en filosofiese relativistiese beskouinge, lees egter die verse onder meer 'teen die grein' en kom so tot 'n herskrywing van die poëtiese, ideologiese en filosofiese onderbou van die poësie.

Die artikels kom herhaaldelik terug op bepaalde temas in Cloete se werk, temas soos onder meer lyding, soeke na God, die natuur as skepping van God, die verhouding tussen die mens en die aarde en God. Die digter se voorliefde vir patroonmatigheid word telkens aangetoon in sy gevoel vir struktuur en ordening, in sy raaksien van ooreenkomste, in die enumerasietegniek, in die voorliefde vir getalle en getallepatrone. Daar word ook telkens gesuggereer dat die werklikheid beheers of besweer en waardeer word deur te sien én te verwoord.

Die artikels gee 'n goeie oorsig oor Cloete se poëtikale opvatting en poëtiese procédé, maar verder sal die leser 'n duidelike beeld kan vorm van die lewensbeskoulike dimensie van sy werk. Die verskeidenheid van literêrteoretiese invalshoeke en die verskillende konklusies is nie net 'n aanduiding van die veelfassetigheid van die studies nie, maar ook 'n bewys van die veelsydigheid van Cloete se werk wat vele aangesigte vertoon en vele uitnodigings tot ondersoek en analise en bespiegeling tot die leser en student rig.

\section{Litera}

Die afdeling Litera word in hierdie nommer van Literator doelbewus op die tema van die nommer afgestem: daar moet nie net oor die verse en verhale van Cloete gepraat word nie, kreatiewe tekste oor en van Cloete moet ook 'n plek kry om die literêre gesprek aan die gang te hou.

Litera word ingelui deur 'n skets van Henriette Grové, waarin sy, as 'n vriendin oor baie jare, Cloete sien op die plekke waar hy was en is. Daar spreek uit die stuk nie net waardering en toegeneentheid nie, maar 'n diep begrip vir Cloete se verbondenheid aan die aarde, dié bekende pool in die spanningsveld tussen hemel en aarde.

Vir die viering van T.T. Cloete se sewentigste verjaarsdag op 31 Mei 1994 in die Totiushuismuseum in Potchefstroom, het Hans du Plessis 'n huldigings- en gelukwensingsgedig geskryf en voorgedra. Die gedig, "Huldig", doen ook hier in dié bundel wat sy titel sê. Hierna volg 'n gedig van Mariana Venter oor Cloete as Psalmberymer. 
Uit die pen van Cloete word twee gedigte uit Met die aarde praat geplaas, asook drie nuwe ongepubliseerde gedigte, "Geringe dinge", "wolke" en "Oranjerivier". Prof. Cloete het die nuwe gedigte spesiaal in sy handskrif oorgeskryf met die oog op publikasie in Literator, maar hy het toe nie geweet dat die hele tydskrif aan hom opgedra word nie. Ter wille van 'ontoereikende leeslasers' (sonder verwysing na die digter se handskrif?) word die verse ook in druk geplaas. Prof. D.H. Steenberg het twee Cloete-gedigte vertaal en met Cloete se instemming verskyn die vertalings hier.

Daarna volg twee nuwe verhale, "Vier hoekhuise" en "Op jouself lyk" - die eerste prosawerk wat Cloete laat publiseer sedert die verskyning van Die waarheid gelieg in 1984.

Litera word afgesluit met twee voorbeelde van Cloete se werk aan die omdigting van die Psalms. Die kompleksiteit van so 'n omdigtingsproses word kortliks verduidelik in 'n kort kommentariënde voorwoord en 'n moontlike lesersinterpretasie van Psalm 65:5 deur Mariana Venter. Dat die omdigtingsproses ook soms verdigting van gegewens tot gevolg het, word geillustreer deur 'n lesing van die 1983-vertaling van die Bybelteks en die berymde Cloete-teks te vergelyk. Die geduld en volharding wat dié soort werk vereis, blyk uit die verskil tussen die voorstadium en die voorfmale stadium van Psalm 90, terwyl die finale vorm van Psalm 65:5 'n aanduiding gee van die kwaliteit van die eindproduk.

\section{Bibliografiese inligting}

Die redaksie van Literator wil met hierdie nommer 'n bydrae lewer tot die bestudering van die werk van T.T. Cloete, maar wil ook 'n bydrae maak tot literêre navorsing in die algemeen. Daarom word die inleiding gevolg deur 'n uitvoerige bibliografie (vgl. Bylaag 2) van studies oor Cloete se kreatiewe werk, sodat 'n verskeidenheid van relevante inligting oor die skrywer se werk hier byeengebring word. Hiermee hoop die redaksie dat die tydskrif nuttig sal wees vir navorsers en studente.

Hierdie bibliografie sluit nie Cloete se eie teoretiese en wetenskaplike geskrifte en studies oor die letterkunde of resensies van wetenskaplike publikasies waarvan Cloete die outeur was, in nie. In die bundel opstelle In teen die groot vergeet wat met Cloete se sestigste verjaarsdag in 1984 saamgestel is, verskyn daar 'n bibliografie van boeke en artikels waarvan Cloete outeur was. Die bibliografie wat hier in Literator verskyn, is opgestel deur Mariana Venter en bevat slegs wetenskaplike werk oor Cloete as kreatiewe skrywer. Die lys van proefskrifte, verhandelings, tydskrifartikels, tydskrifresensies en hoofstukke in bundels in die bibliografie is rekenaarmatig opgespoor volgens die mees voor 
die hand liggende (Cloete)-trefwoorde, maar kan uiteraard nie op volledigheid aanspraak maak nie. Oor sy digbundels het byvoorbeeld ongeveer 36 koerantresensies verskyn wat nie hier ingesluit is nie. Die bibliografie bestaan uit twee dele: afdeling 1 bevat proefskrifte en verhandelings wat in geheel of gedeeltelik oor Cloete se oeuvre handel, en afdeling 2 bevat die tydskrifartikels en studies in versamelbundels.

Die twee bibliografieë, dié een in Literator 16(3)1995 met die lys van studies oor Cloete se kreatiewe werk en die een in In teen die groot vergeet (1984) met Cloete se wetenskaplike bydraes, behoort dus eintlik saam gebruik te word en kan die basis vorm vir omvattender bibliografiese navorsing rondom Cloete as literêre figuur in die wye sin van die woord.

\section{Ten slotte}

Die redaksie van Literator vertrou dat hierdie bundel nie net aan die werk van die digter-literator T.T. Cloete laat reg geskied nie, maar dat dit ook 'n waardige bron sal wees vir ander navorsers oor die werk van hierdie skrywer.

\section{Bylaag 1: Toekennings}

- Gustav Preller-prys vir literatuurwetenskaplike navorsing van SA Akademie - 1976

- Ingrid Jonker-prys vir poësie vir Angelliera - 1981

- Hofmeyr-toekenning vir poësie vir Angelliera - 1981

- Louis Luyt-toekenning vir poësie vir Jukstaposisie - 1983

- Hofmeyr-toekenning vir poësie vir Allotroop - 1986

- CNA-toekenning vir poësie vir Allotroop - 1986

- Hertzog-prys vir poësie vir Allotroop en Idiolek - 1987

- Hofmeyr-toekenning vir poësie vir Driepas - 1989

- Rapportryers-prys vir digwerk - 1990

- Staatspresidentstoekenning (OVDG - Orde vir Voortreflike Diens - Goud) $-1992$

- Hertzog-prys vir poësie vir Met die aarde praat - 1993

- Rapport-prys vir Met die aarde praat - 1993

- Eredoktorsgraad van die PU vir CHO - 1986 
Bylaag 2

\section{'n Bibliografie' oor veral die kreatiewe werk van T.T. Cloete (1980-1994)}

\section{Proefskrifte en verhandelings oor die werk van T.T. Cloete}

Basson, C.H. 1987. Die in memoriam-verse as nukleusgedigte in Allotroop. Pretoria : UNISA. (M.A.-verhandeling.)

Beukes, M.P. 1989. Vooropstelling, kohesie in die poësie van T.T. Cloete. Potchefstroom : PUCHO. (M.A.-verhandeling.)

Bosman, M.E. 1989. Op Hom die groot hosannas: enkele aspekte van die moderne Christelike poësie in Afrikaans. Grahamstad : Rhodes Universiteit. (D.Phil.-proefskrif.) (Hoofstuk 4: "T.T. Cloete: hedendaagse Totius?")

Buscop, J. 1989. Job as geobjektiveerde spieëlbeeld van T.T. Cloete: 'n struktureel-semantiese lesing. Pretoria : UP. (M.A.-verhandeling.)

Gouws, T. 1988. Die transskriptuele lees, hiaat, haplografie en transkripsie in die poësie van Breytenbach, Krog en Cloete; 'n logolinguale lesing. Potchefstroom : PUCHO. (D.Litt.-proefskrif.)

Jooste, E. 1989. Idiolek van T.T. Cloete: vers, sin en Woord in jukstaposisie. Potchefstroom : PUCHO. (D.Litt.-proefskrif.)

Nel, A. 1993. Die allotropie van gevormde literatuur in die poësie van T.T. Cloete: 'n ondersoek van die idiolektiese "omzetting" van Nederlandse tekste. Pretoria : UP. (D.Litt.-proefskrif.)

Robinson, A.S. 1991. Poësieteks en Bybelse interteks. Potchefstroom : PUCHO. (D.Litt.-proefskrif.)

Van der Walt, M.J. 1988. Die verwerking van Bybelse materiaal in die poësie van T.T. Cloete. Pretoria : UNISA. (M.A.-verhandeling.)

Van Jaarsveld, A.E. 1993. Driepas (T.T. Cloete)-die digter as dissipel; die taal as katedraal. Mmabatho : Universiteit van Bophuthatswana. (D.Littproefskrif.)

1 My dank aan Bernard Odendaal (UOVS) vir die aanvul van inligting vir hierdie bibliografie - Mariana Venter. 
Van Niekerk, F.C. 1988. Struktuurprinsipes in Jukstaposisie-T.T. Cloete. Pietermaritzburg : UN(P). (M.A.-verhandeling.)

Van Rensburg, J.H.J. 1991. Die jukstaponering van hemel en aarde in die poësie van T.T. Cloete. Potchefstroom : PUCHO. (M.A.-verhandeling.)

Venter, I.L. 1988. Intergedigtelike verhoudings in die poësie van T.T. Cloete, met Jukstaposisie as vertrekpunt. Pretoria : UP. (D.Litt.-proefskrif.)

Visagie, J.A.G. 1987. T.T. Cloete as eksponent van die moderne Afrikaanse poësie soos hy dit self gekarakteriseer het in Die Afrikaanse literatuur sedert Sestig. Pretoria : UNISA. (M.A.-verhandeling.)

\section{Tydskrifartikels, tydskrifresensies en bydraes in versamelbundels oor aspekte van die werk van T.T. Cloete}

Beukes, M.P. 1994. Ritme heel die beenbreekbaarheid in "Skouspel 1" en "Glasbreekbaar" van T.T. Cloete. Tydskrif vir Letterkunde, 32(4):107114.

Botha, E. 1984. Verslag van 'n debuut: T.T. Cloete se prosatekste. In: Viljoen, H., Gräbe, I., Jooste, E., Steenberg, D. In teen die groot vergeet. Potchefstroom : PU vir CHO. p. 14-25. (Wetenskaplike bydraes van die PU vir CHO. Reeks A44: Geesteswetenskappe.)

Brink, A.P. 1981. Poësie 1980: Swaarweer en kleinwind. Standpunte 154, 34(4):29-45.

Buscop, J. 1991. "Prediker" van T.T. Cloete. Klasgids, 26(1):59-66.

Cilliers, L. 1987. "Catullus XXXI": 'n interpretasie. Akroterion, 32(3):7583.

Coetzee, G.H.J. 1993. Swaeltjies wat luistervink speel! Lantern, 42(1):66-67, Feb. ("Luisterswaeltjies".)

Conradie, M. 1990. Hoor en sien vergaan nié by Cloete nie. Ensovoort, 4(1):5-6, Mei.

Crous, M. 1990. In gesprek (met) Allotroop. Spits, 6(1):32-39.

De Kock, A. 1994. T.T. Cloete word 70. Lantern, 43(4):43-37, Okt.

Du Plessis, S. Voorgeskrewe gedigte 1991. Klasgids, 27(1):54-59, Feb. ("Prediker 12".)

De Villiers, P.G.R. 1991. Die vernietiging van die bose. Voorbeelde van apokaliptiese denke in die Afrikaanse digkuns. Tydskrif vir Geesteswetenskappe, 31(3):217-231.

De Vries, A.H. 1989. T.T. Cloete. Kortom:174-177.

Du Plooy, H. 1993. Die heelal in 'n taalkristal. Die poësie van T.T. Cloete. Woordwerk, 11(43):19-36. 
Ester, H. 1984. Het bewuste virtuositeit van T.T. Cloete. Zuid-Afrika, 61(11/12).

Gilfillan, F.R. 1991. Die Afrikaanse poësie van die tagtigerjare: 'n indruk. Stilet, 3(1):47-56.

Gouws, T. 1989. Die transkripsielees van T.T. Cloete. Literator, 10(3):31-47. Gouws, T. 1990. T.T. Cloete. 'n Ster is in die hemel versit. Insig:44-45, April.

Gräbe, I. 1982. Tematiese verskeidenheid en poëtiese samehang in T.T. Cloete se volwasse debuutbundel Angelliera. Tydskrif vir Letterkunde, 20(1):9396, Feb.

Gräbe, I. 1984a. Eksploitasie van klankmatige aspekte in T.T. Cloete se Jukstaposisie. In: Viljoen, H., Gräbe, I., Jooste, E. \& Steenberg, D. In teen die groot vergeet. Potchefstroom : PU vir CHO. p. 25-53. (Wetenskaplike bydraes van die PU vir CHO. Reeks A44: Geesteswetenskappe.)

Gräbe, I. 1984b. (Bespreking van) Jukstaposisie. Tydskrif vir Letterkunde, 22(1):93-96, Feb.

Gräbe, I. \& Pretorius, R. 1981. Angelliera van twee kante bekyk. Tydskrif vir Letterkunde, 19(2):69-83, Mei.

Grové, A.P. 1981. Die aarde en die volheid daarvan (T.T. Cloete se Angelliera, Tafelberg 1980). Tydskrif vir Letterkunde, 19(1):78-82.

Grové, A.P. 1983. Kanttekeninge by die begrip jukstaposisie. In: Sinclair, A.J.L. (red.) G.S. Nienaber 'n huldeblyk. Bellville : Universiteit van Wes-Kaapland. p. 235-238.

Grové, A.P. 1984. Syfers en somtotaal. In: Viljoen, H., Gräbe, I., Jooste, E. \& Steenberg, D. In teen die groot vergeet. Potchefstroom : PU vir CHO. p. 56-63. (Wetenskaplike bydraes van die PU vir CHO. Reeks A44.)

Grové, A.P. 1987. Poësiekroniek: Leef uit 'n tradisie. Tydskrif vir Geesteswetenskappe, 27(2):148-156. (Idiolek.)

Grové, A.P. 1993a. Cloete soek met oog, oor en tong. Insig: B3, Februarie.

Grové, A.P. 1993b. Poësiekroniek. Tydskrif vir Geesteswetenskappe, 33(3):230-238, Sept. (Met die aarde praat.)

Hambidge, J. 1982. Nota by Rena Pretorius se bespreking van T.T. Cloete, Angelliera. Tydskrif vir Letterkunde, 20(1):74, Feb.

Hambidge, J. 1984a. Bestekopname: T.T. Cloete se Angelliera en Jukstaposisie. Standpunte, 37(3):57-64.

Hambidge, J. 1984b. 'n Herwaardering van Jukstaposisie. Ensovoort, 4(1):79, Mei.

Hambidge, J. 1986a. "Marilyn Monroe foto in blou": 'n dekonstruksie van die gedig as fototeks. (Hoofstuk 5.) In: Senekal, J. Teks, leser, konteks - 
gedigte ontleed volgens eietydse metodes. Johannesburg : Perskor. p. 6879.

Hambidge, J. 1990. Resensie: Driepas. Literator, 11(2):128-129.

Jacobs, J.F. 1988. "Artefaktereëel"-T.T. Cloete. Klasgids, 23(3):105-107.

Kannemeyer, J.C. 1988. Die Afrikaanse literatuur 1652-1987. Pretoria : Academica. p. 446-455.

Lewis, J. 1994a. "Luisterswaeltjies": T.T. Cloete. Klasgids, 29(1):32, Feb.

Lewis, J. 1994b. Drie verhale voorgeskryf deur die Departement van Onderwys en Opleiding. Klasgids, 29(2):14-17, Mei. ("Die ramp".)

Lindenberg, E. 1993. Met die aarde praat, T.T. Cloete: 'n resensie. De Kat, 8(11):87, Mei.

Malan, C. 1984. Die fyn essensie van "stukkies mens en wêreld" in Jukstaposisie. Ensovoort, 4(1):10-11, Mei.

Malan, L. 1987. Idiolek, T.T. Cloete 'n boekresensie. De Kat, 2(8):100, Maart.

Marais, R. 1984. Gesins- en familiegedigte in die poësie van T.T. Cloete. Ensovoort, 4(1):10-11, Mei.

Nienaber, C.J.M. 1983. Cloete en vliegtuigie op handjie. (Oor Jukstaposisie.) Standpunte, 36(1):56-64, Feb.

Nienaber, C.J.M. 1984. U troetelvissie T.T. Cloete. In: Viljoen, H., Gräbe, I., Jooste, E. \& Steenberg, D. In teen die groot vergeet. Potchefstroom : PU vir CHO. p. 64-78. (Wetenskaplike bydraes van die PU vir CHO. Reeks A44: Geesteswetenskappe.)

Odendaal, B.J. 1991. Sien (en hoor!) is glo; 'n voorlopige verkenning van ikonisiteit as retoriese strategie aan die hand van twee kort gedigte. Literator, 12(3):13-23, Nov. ("God die digter".)

Odendaal, B.J. 1993a. Die buitengewone woord as verkenningsintuig in die poësie van Peter Blum en T.T. Cloete. Stilet, 1:83-98.

Odendaal, B.J. 1993b. Via alruin en seks tot God: die eiesoortige mistiek in die poësie van T.T. Cloete. Literator, 14(2):1-23.

Odendaal. B. 1994. Bespreking van vier voorgeskrewe gedigte vir matriek (OVS). Klasgids, 29(2):11-13, Mei. ("Arktiese swael".)

Odendaal, L.B. 1987. Dramakroniek. Tydskrif vir Geesteswetenskappe, 27(3):254-263. (Onderhoud met 'n bobbejaan.)

Ohlhoff, H. 1984. Wetenskap en poësie. Ensovoort, 4(1):18-20, Mei.

Olivier, F. 1980. Die Afrikaanse poësie van vandag. Standpunte, 150, 33(6):25-30, Des.

Pieterse, H. 1991. Poësie uit drie bloemlesings. Tydskrif vir Letterkunde, 29(1):108-118. ("Koppe".)

Pieterse. H. 1992. Voorgeskrewe poësie. Klasgids, 27(2):19-30, Mei. 
("Prediker 12".)

Potgieter, S. 1988. Orde en ordelikheid in Idiolek van T.T. Cloete. Klasgids, 23(1):6-9, Feb.

Pretorius, R. 1981. Angelliera: van twee kante bekyk. Tydskrif vir Letterkunde, 19(2):27-37, Mei.

Pretorius, R. 1984. Skouspel en Carcasonne: die "klankdenke" in Jukstaposisie. In: Viljoen, H., Gräbe, I., Jooste, E. \& Steenberg, D. In teen die groot vergeet. Potchefstroom : PU vir CHO. p. 79-92. (Wetenskaplike bydraes van die PU vir CHO. Reeks A44: Geesteswetenskappe.)

Pretorius, R. 1987. Kanttekeninge by T.T. Cloete se vierde digbundel. Tydskrif vir Letterkunde, 25(2):27-37. (Idiolek.)

Pretorius, R. 1994. Met die aarde praat (1992): Alles wys en fyn beplan. Tydskrif vir Letterkunde, 32(1):110-113, Feb.

Pretorius, W. 1980. Die Afrikaanse poësie van vandag. Standpunte 150, 33(6):32-32, Des.

Roos, Henriette. 1986. Van twee debute uit twee wêrelde. Standpunte, 39(4):45-59.

Rossouw, M. 1984. T.T. Cloete as literator. Ensovoort, 4(1):23-24, Mei.

Scholtz, Merwe. 1984. Die digter as leser. In: Viljoen, H., Gräbe, I., Jooste, E. \& Steenberg, D. In teen die groot vergeet. Potchefstroom : PU vir CHO. p. 108-116. (Wetenskaplike bydraes van die PU vir CHO. Reeks A44: Geesteswetenskappe.)

Schutte, H.J. 1984. 'n Poëtika van korrespondensies: Angelliera en Jukstaposisie. In: Viljoen, H., Gräbe, I., Jooste, E. \& Steenberg, D. In teen die groot vergeet. Potchefstroom : PU vir CHO. p. 93-107. (Wetenskaplike bydraes van die PU vir CHO. Reeks A44: Geesteswetenskappe.)

Schutte, H.J. 1987. Drama. Tydskrif vir Letterkunde, 25(1):87-98, Feb. (Onderhoud met 'n bobbejaan.)

Schutte, R. 1991. 'n Inleiding tot poësieontleding en interpretasie (vervolg). ("Moreson".) Klasgids, 4(1)33:71.

Smith, M.E. 1987. Aantekeninge by ses gedigte uit Skakering. Klasgids, 22(4):22-29. ("Luisterswaeltjies".)

Smith, M.E. 1988. Voorgeskrewe gedigte uit Senior Verseboek. ("Dito's".) Klasgids, 23(3):95-96, Mei.

Smuts, R. 1993. Angel en lier en angelier en "Behoefte aan ongunstige weeren ander omstandighede". Tydskrif vir Letterkunde, 31(3):120-127.

Spies, L. 1983. 'n Nuwe bloei in Afrikaans: T.T. Cloete se angelier, Antjie Krog se roos. In: Botha, E. \& Pretorius, R. (reds.) Samehang en sin: Opstelle oor die Afrikaanse poësie, aangebied aan prof A.P. Grove by 
geleentheid van sy vyf en sestigste verjaardag op 10 Junie 1983. Kaapstad : Tafelberg. p. 106-120.

Spies, L. 1984. Geloof en gedig in die Afrikaanse poësie van Sewentig. Ensovoort, 4(1):25-28, Mei.

Swanepoel, J. 1981. Poësie van verskeidenheid en verband: 'n bespreking van T.T. Cloete se Angelliera. Literator, 2(1):53-63.

Van Niekerk, F. 1984. Die motto in Jukstaposisie. Ensovoort, 4(1):30-35, Mei.

Van der Spoel, C. 1994. 'n Gedig is 'n pasella sê Cloete. Insig: B8, September.

Van der Walt. P.D. 1984. Die waarheid gelieg. Woord en Daad, Oktober.

Van der Westhuizen, B. 1993. Die in-/deurwerking van die Griekse mitologie in Driepas van T.T. Cloete. Stilet, 1:65-82.

Van Heerden, J. 1988. T.T. Cloete: Onderhoud met 'n bobbejaan. South African Theatre Journal, 2(1):78-80.

Van Zyl, I. 1987. Voorgeskrewe gedigte: literêre kritiek. Klasgids, 22(3):4851, Aug. ("koppe" en "Nagtelike miriorama".)

Van Zyl, E.A. \& Van Rensburg, F.I.J. 1990. Die dodegedig in Afrikaans. Spits, 6(1):22-31.

Van Zyl, W. 1993. "Van 'n paddastoeltuin" tot "Kamikaze", gedigte uit Senior Keur. Klasgids, 28(2):32-33, Mei. ("Paddastoeltuin".)

Venter, Leona. 1988. "Philosophers (are) hard to kill" ('n verkenning van die 'aanwysbare' filosofiese interteks). Tydskrif vir Geesteswetenskappe, 28 (4):357-367.

Venter, Leona. 1990. Die "denk" rondom die dood by T.T. Cloete. Tydskrif' vir Letterkunde, 28(3):51-63. ("Gebreekte bene", "Egidius", "Alle grappies op 'n stokkie".)

Venter, Leona. 1991. Die praktyk van kyk. Tydskrif vir Letterkunde, 29(3):69-75. ("Kameelperd".)

Venter, I.L. 1993. Vondste uit de oude doos: Hommage à T.T. Cloete. Literator, 14(3):71-84, Nov.

Viljoen, H. 1989. Dik en dun, gesirkuleer en afgestroop - kringlope om 'n gedig van T.T Cloete. Literator, 10(2):45-49. ("uitgedun".)

Viljoen, H.M. 1987. Metafore en rame. Journal of Literary Studies, 3(2):5777, Jul. ("Sweef".)

Visagie, J.A.G. 1988. Fasette van T.T. Cloete se digkuns - "Die bruin van die aarde en die blou van die hemel". Klasgids, 23(2):99-111.

Wissing, D.P. 1984. Die rym in Jukstaposisie (T.T. Cloete) en die regverdiging van enkele fonologiese begrippe. Literator, 5(1):94-97. 